\title{
Professional Creativity as A Component of The Effective Activity of a Teacher
}

\section{La Creatividad Profesional Como Componente de la Actividad Efectiva de un Docente}

\author{
Konstantin Zaurovich Abdula-Zade \\ Athlete-instructor of the Center for Sports Training of National Teams of Russia, Moscow, \\ Russia \\ https://orcid.org/0000-0003-4145-0123
}

Marina Georgiyevna Sergeeva

Doctor of Pedagogical Sciences, Assistant Professor, Chief Researcher, Research Institute of the Federal Penitentiary Service of Russia, Moscow, Russia https://orcid.org/0000-0001-8365-6088

\section{Dmitry Vladimirovich Lukashenko}

Doctor of Psychological Sciences, Associate Professor, Leading Researcher, Research Institute of the Federal Penitentiary Service of the Russian Federation, Moscow, Russia

https://orcid.org/0000-0002-0045-6062

Anna Viktorovna Solovieva

Candidate of Pedagogical Sciences, Associate Professor, Department of Architecture Academy of Engineering, Peoples' Friendship University of Russia (RUDN University), Moscow, Russia https://orcid.org/0000-0003-2175-8593

Received 09-08-20 Revised 10-10-20

Accepted 12-12-20 On line 03-18-21

*Correspondencia

Email: petrmar2005@mail.ru
Citar como:

Abdula-Zade, K. Sergeeva, M., Lukashenko, D., \& Solovieva, A. (2021). Professional Creativity as A Component of The Effective Activity of a Teacher. Propósitos y Representaciones, 9 (SPE3), e1177. Doi: http://dx.doi.org/10.20511/pyr2021.v9nSPE3.1177 


\section{Summary}

The article considers the role and influence of professional creativity on the professional activities as an expression of the teacher's creative abilities. The purpose of the article is a theoretical and empirical study of the influence of professional creativity on the effectiveness of a teacher's professional activity. Attention is paid to the place and importance of creativity in the activities of a teacher. Based on an analysis of current literary sources, the phenomenon of professional creativity of a teacher is highlighted, a definition of this concept is given, and its structure and components are considered. The research methodology and its algorithm include a complex psychological and pedagogical experiment, diagnosing the stated parameters and statistical analysis of the results based on Spearman's rank correlation coefficient. The study of teachers' creativity was carried out on the basis of the Institute of Foreign Languages of the Federal State Autonomous Educational Institution of Higher Education "The Peoples' Friendship University of Russia" (RUDN) at the Center for Continuing Professional Education. For research purposes, an experimental and a control group were formed. Each group consisted of 35 teachers. The sample was homogeneous by age and gender. The results of the study allow us to conclude that there is a strong relationship between the professional creativity of a teacher and the effectiveness of the professional performance, which is confirmed by the results of statistical processing of the data obtained.

Keywords: Professional Creativity, Professional Competence, Higher Education.

\section{Resumen}

El artículo considera el papel y la influencia de la creatividad profesional en las actividades profesionales como expresión de la capacidad creativa del docente. El propósito del artículo es un estudio teórico y empírico de la influencia de la creatividad profesional en la efectividad de la actividad profesional de un docente. Se presta atención al lugar y la importancia de la creatividad en las actividades de un docente. A partir de un análisis de las fuentes literarias actuales, se destaca el fenómeno de la creatividad profesional de un docente, se da una definición de este concepto y se considera su estructura y componentes. La metodología de investigación y su algoritmo incluyen un experimento psicológico y pedagógico complejo, diagnosticando los parámetros establecidos y análisis estadístico de los resultados con base en el coeficiente de correlación de rangos de Spearman. El estudio de la creatividad de los profesores se llevó a cabo sobre la base del Instituto de Lenguas Extranjeras de la Institución Educativa Autónoma de Educación Superior del Estado Federal "Universidad de la Amistad de los Pueblos de Rusia" (RUDN) en el Centro de Educación Profesional Continua. Con fines de investigación, se formó un grupo experimental y uno de control. Cada grupo estaba formado por 35 profesores. La muestra fue homogénea por edad y sexo. Los resultados del estudio permiten concluir que existe una fuerte relación entre la creatividad profesional de un docente y la efectividad del desempeño profesional, lo cual es confirmado por los resultados del procesamiento estadístico de los datos obtenidos.

Palabras clave: Creatividad profesional, Competencia profesional, Educación superior.

\section{Introducción}

The social demand for highly professional teachers in Russia was expressed in the system of requirements imposed by society for personal and professional demonstration of competence and performance. This is confirmed by the increasingly widespread introduction of the competence-based approach in education, which has made profound changes in the fundamental foundations of higher education. The needs for high quality professional performance, the desire for pedagogical self-improvement, the effective use of creative potential in solving significant professional tasks and productive functioning should become the leading directions in the system of teacher's professional development. 
Creative thinking and the ability to find a way out of any given situation are the integral parts of the mechanism called pedagogical creativity. A teacher of a modern school or university should have in-depth knowledge of the methodological and organizational side of the subject and means of pedagogical support for the development of each child's personality, the development of the students' readiness for mobility and flexibility in a constantly changing world and developing society (Dolzhich, Dmitrichenkova, 2018).

Among other skills, the teacher should have the skills to find an individual approach to each student, to understand and identify the most problematic areas in teaching children. It is also worth noting that through creativity, the teacher should be able to interest students, arouse their desire for knowledge and a sufficient level of motivation. Education should teach not only to memorize theoretical material and not be limited to measuring the learning outcomes as a result of studying a subject, but to consider this issue creatively and form vital competencies.

This has necessitated the study of creativity as an integral part of the teacher's professional competence, which, within the framework of the competence-based approach, is understood as professional creative competence, or professional creativity.

\section{Literature review}

The content-richness of the components of the teacher's professional creativity could be represented on the basis of the creativity parameters studied by E. Torrens, D.B. Bogoyavlenskaya, E.E. Tunik, V.V. Moroz, D. Keyfer, J.R. Averill, Z. Ivcevic, M.A. Runco and others (Vasbieva et al., 2018; Bírová et al., 2018; Volkova, Panchenko, 2018; Blinova et al., 2018) (Table 1).

Table (1): Content of the components of the teacher's professional creativity

\begin{tabular}{|c|c|}
\hline \multicolumn{2}{|c|}{ Teacher's professional creativity } \\
\hline Components & Content of the components \\
\hline Intellectual creativity & $\begin{array}{c}\text { Originality, flexibility, fluency, elaboration, richness and } \\
\text { brightness of associations }\end{array}$ \\
\hline Individual creativity & $\begin{array}{l}\text { Imagination, the complexity of aspects of self-expression, } \\
\text { curiosity, impulsiveness, the need for creativity }\end{array}$ \\
\hline Social creativity & $\begin{array}{l}\text { Expression, plasticity of the creative process, sensitivity } \\
\text { to social phenomena. }\end{array}$ \\
\hline Emotional creativity & $\begin{array}{l}\text { Innovation, efficiency of performance and assessment, } \\
\text { the uniqueness of emotional states }\end{array}$ \\
\hline
\end{tabular}

Distinguishing of such elements as intellectual, personal, social and emotional creativity in the structure of professional creativity is predicated on the specifics of the teacher's professional activity. When considering the problem of the professionally important qualities of a teacher and the characteristics of professional activity, the following conclusions were drawn as the basis for determining the structure and clarifying the formulation of the concept of the teacher's professional creativity:

- the psychological profession as a profession of the "person-person" group is socially oriented, which implies the presence of a high level of such quality as social intelligence. In turn, as Mark A. Runco noted, social creativity is a kind of derivative of social intelligence, positioned as divergent thinking in the field of social and communicative situations (Runco, 2015). In this regard, we consider the presence of social creativity in the structure of components of professional creativity reasonable;

- the overwhelming majority of researchers consider the psychological profession to be personality-oriented, therefore, requiring highly developed personal qualities. Individual creativity is the creative expression of one's own individuality. For example, V.V. Moroz and 
Oon-Seng Tan believe that personality manifestations are essential for effective teacher performance. In this regard, we believe that the important place of this parameter in the structure of professional creativity is justifiable (Moroz, 2011; Oon-Seng, 2017). Also, this quality correlates with A. Maslow's creativity of self-realization;

- psychological activity requires a well-developed emotional sphere, empathic abilities, understanding of emotions and experiences of other people (Averill, 2015). This ability to create new, original emotional experiences (J. R. Averill) is essential for effective entry into the psychological profession. Based on the listed arguments, we consider it reasonable to include emotional creativity in the structure of professional creativity;

- intellectual creativity, actually divergent thinking, is the basis of any creative manifestations, and its place in the structure of the teacher's professional creativity is axiomatic (Bogoyavlenskaya, 2016; 2017; Bogoyavlenskaya, Kotlyarova, 2017a; 2017b; Ivcevic et al., 2015).

The synergy of these components forms a new quality, which can be defined as the teacher's professional creativity. This structure of professional creativity arises from the specifics of teaching performance and professionally important qualities of a teacher (Gorev et al., 2018).

\section{Proposed Methodology}

The main task of our research is to bring together the theoretical knowledge and practical experience accumulated in this area into a single system.

The study of teachers' creativity was carried out on the basis of the Institute of Foreign Languages of the Federal State Autonomous Educational Institution of Higher Education "The Peoples' Friendship University of Russia" (RUDN) at the Center for Continuing Professional Education. For research purposes an experimental and a control group were formed. Each group consisted of 35 people. The sample was homogeneous by age and gender.

The purpose of the article is a theoretical and empirical study of the influence of professional creativity on the effectiveness of a teacher's professional performance. To achieve this goal, a complex psychological experiment was carried out, including a problem-search method, a cross-sectional method and an experiment method.

In the course of organizing the experiment, the studied parameters were determined:

- intellectual creativity;

- individual creativity;

- social creativity;

- emotional creativity (Sharonova et al., 2018).

In the experimental study, the following diagnostic techniques were used:

- intellectual creativity: a modified and adapted version of the Creativity Assessment Packet CAP, developed by Frank E. Williams;

- individual creativity: diagnostics of personal creativity of E.E. Tunic; 
R. Averill;

- emotional creativity: an adapted version of the Emotional Creativity Inventory of J.

- social creativity: modeling of social situations of D. Keyfer, MS;

- a set of methods for assessing the teacher's professionalism and the effectiveness of solving professional problems developed by A.V. Raspopov, L. L. Akimova.

In the course of the experimental study, a number of diagnostic tasks and a qualitative analysis of the results obtained were implemented. In the control and experimental groups, the actions presented in Table 2 were performed.

Table (2): Algorithm of actions in the course of the experiment

Algorithm of actions
1) diagnostics of the structural components of creativity: intellectual, individual,
social and emotional creativity;

\section{Result Analysis}

The results of the experimental study are graphically presented in the form of diagrams. Generalized scale of measurements from 1 to 100, criteria for assessing significance:

1 - 27 - low level;

27 - 59 - intermediate level;

59 - 77 - high level;

77 - 100 - very high level.

The diagnostic results are shown in Fig. 1. 


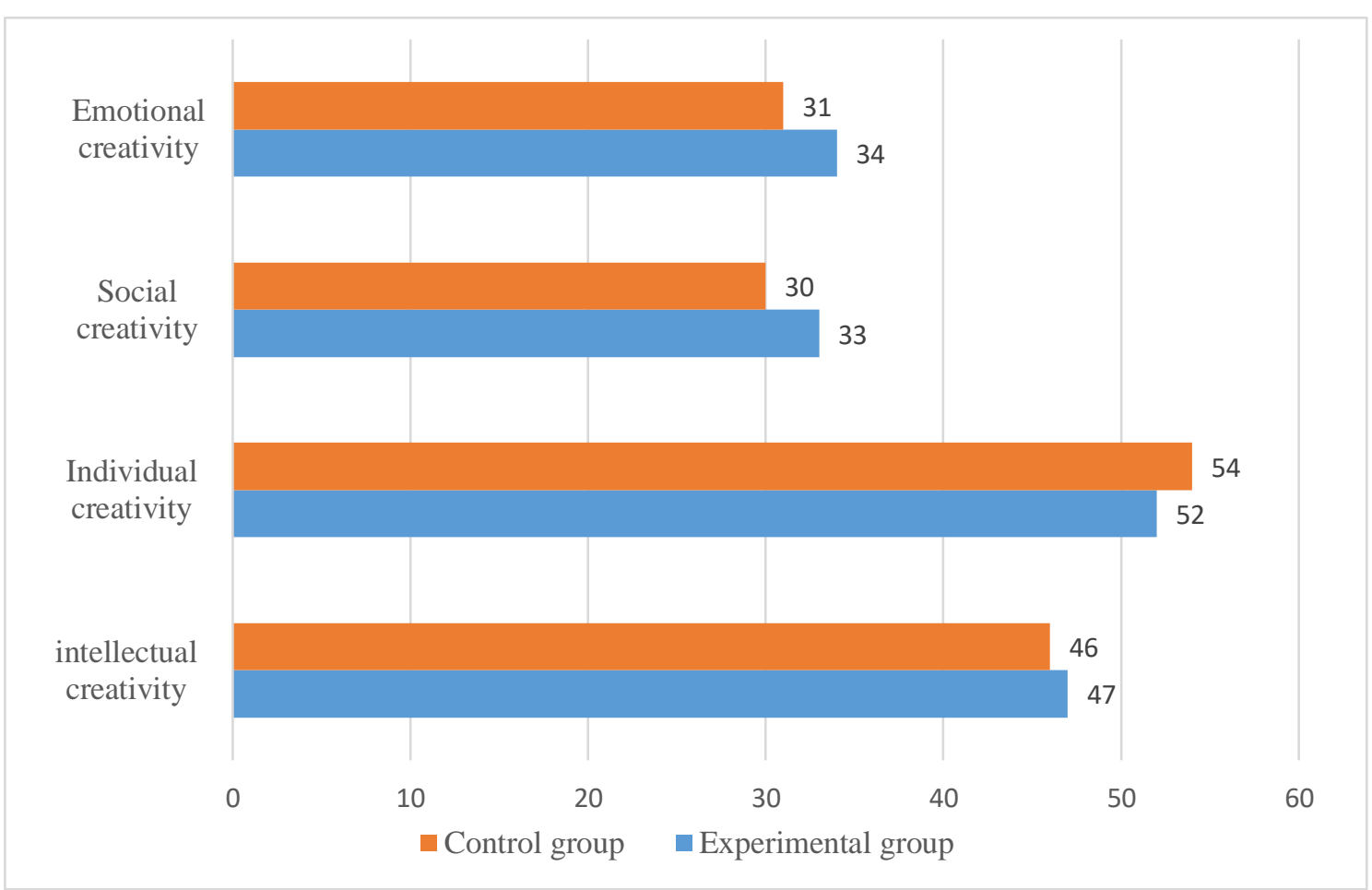

Figure (1): Diagnostics results of the structural components of creativity

The results obtained indicate a predominantly intermediate level of development of all professional creativity components in the control and experimental groups. This is consistent with the development norms identified by J. R. Averill that are characteristic of young persons and adults (Averill, 2015).

The diagnostic results of both groups are practically identical, with the exception of minor deviations. It should be noted that the only component of a teacher's creativity that has a high level of development is the individual creativity. According to D. Keyfer (2008), individual creativity is a kind of foundation for the development of creative abilities in specialists whose career is associated with social or interpersonal interaction.

The effectiveness of solving professional problems was diagnosed using a set of methods for assessing the professionalism of a teacher and the effectiveness of solving professional problems (A.V. Raspopov, L.L. Akimova).

The diagnostic results are presented in the form of a diagram in Fig. 2. 


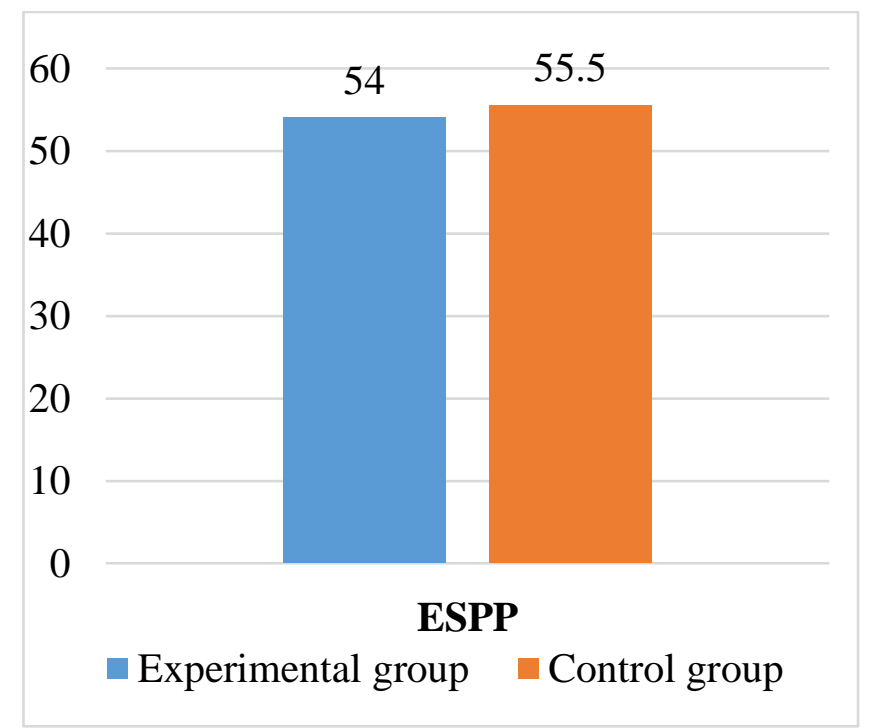

(Figure 2): The diagnostics results of the effectiveness of solving professional problems

The results obtained revealed the intermediate level of efficiency in solving professional problems in both groups of subjects. It should also be noted that all respondents were engaged in practical teaching activities for no more than three years. A small pedagogical experience can be a significant factor, but it also leads to the conclusion that the influence of the experience factor on the research results is negligible.

The analysis of the diagnostic results allows us to conclude that this sample is homogeneous for all indicators, with the exception of insignificant deviations. The indicators are in the range of intermediate values.

In order to establish the strength and depth of relations, a correlation analysis of creativity and efficiency in solving professional problems was carried out. The results are presented as a comparative correlation matrix in Table 3.

(Table 3): Comparative table of correlations between professional creativity (PC) and the effectiveness of solving professional problems (ESPP) of the control and experimental groups at the indicative stage

Parametres Effectiveness of solving professional problems

(ESPP)

$\begin{array}{ccc}\text { Intellectual creativity (TI) } & 0.63 & 0.62 \\ \text { Naming } & & \\ \text { Originality } & 0.60 & 0.59 \\ \quad \text { Fluency } & & \\ \text { Flexibility } & 0.69 & 0.70 \\ \quad \text { Elaboration } & 0.62 & 0.61 \\ \text { Individual creativity (TI) } & & \\ \text { Inquisitiveness } & & \\ \text { Imagination } & 0.60 & 0.60 \\ \text { Complexity } & & \\ \text { Risk-taking } & 0.72 & 0.71 \\ \text { Social creativity (TI) } & 0.70 & 0.70 \\ \text { Expressiveness } & 0.77 & 0.77 \\ \quad \text { Plasticity } & 0.59 & 0.60 \\ \quad \text { Sensibility } & 0.71 & 0.72 \\ \text { Emotional creativity (TI) } & 0.59 & 0.59 \\ \text { Efficiency } & 0.54 & 0.53 \\ \text { Innovation } & & \\ \text { Authenticity } & & \end{array}$

$\mathrm{p} \leq 0,05$ 
TI - total indicator,

PC - professional creativity,

ESPP - the effectiveness of solving professional problems

Correlation analysis data indicate a high and significant relationship between professional creativity and the effectiveness of solving professional problems. The strongest and most significant is the interdependence between ESPP and social and intellectual creativity, which indicates their priority impact on ESPP.

It should also be noted that the most significant for solving professional problems, due to the data presented, are the parameters responsible for the meaningfulness of the creative process (efficiency, expressiveness, complexity, elaboration). Low level of their development in the control and experimental groups explains, in our opinion, the results of the ESPP diagnostics.

Based on the data obtained during the experimental study, it can be concluded that the state of ESPP as a criterion for the effectiveness of the professional activity of teachers largely depends on the level of development of the teacher's professional creativity. The study confirmed that the specificity and stability of the professional creativity development is expressed in the nature of the relations between structural components, ramification and the strength of inner connections.

\section{Conclusion}

In the course of the study, a significant interdependence was established between the professional creativity of a teacher and the effectiveness of professional activity.

The results of the statistical analysis indicate that the meaningfulness of the creative process largely determines the effectiveness of teachers' solution of professional tasks. Thus, its purposeful development could have a significant impact on the development of the teacher's professionalism.

Further research in line with the selected problems requires a larger sample of subjects and a longitudinal survey, which would allow tracing the development of the declared parameters in dynamics, as well as using a wider range of statistical methods.

\section{Referencias}

Averill, J.R. (2015). Emotions as mediators and as products of creative activity, In: J. Kaufman \& J. Baer (Eds.) Creativity across domains: Face of muse. New York: Erlbaum.

Bírová, J., Kružlík, P., Kalimullin, A., Sokolova, N., Haroun, Z., Králik, R., Vasbieva, D. (2018). Mathematical and Statistical Bibliometric Indicators for Scholars in the Field of Romance Languages and Linguistics. EURASIA: Journal of Mathematics, Science and Technology Education, 14(12).

Blinova, S., Dugina, T., Zabolotskikh, A. (2018). Teaching mixed nationality groups (on the example of students from the Northern Caucasus region). INTED2018: Proceedings of the 12th International Technology, Education and Development Conference. Valencia, Spain.

Bogoyavlenskaya D., Kotlyarova L. (2017b). Methodological concepts of building up the creativity typology. Society. Integration. Education. Proceedings of the Scientific Conference, I: 469-477. https://doi.org/10.17770/sie2017vol1.2298

Bogoyavlenskaya, D., Kotlyarova, L. (2017a). A conception of creativity typology: methodological approach, in: Book of proceedings, Clara Pracana \& Mochsel Wang (eds.). 29 April - 1 May, 2017, Budapest, Hungary. InPACT 2017. International Psychological Applications Conference and Trends. World Institute for Advanced Research and Science (W.I.A.R.S) Lisbon, Portugal. 
Bogoyavlenskaya, D.B. (2016). Modeling creativity: contradictions and paradoxes. 7th International Conference on Cognitive Science, Svetlogorsk, pp. 160-161.

Bogoyavlenskaya, D.B. (2017). On the problem of correlating general, special and creative abilities (on the example of mathematical giftedness). Psychology. Journal of the Higher School of Economics, 14(2): 277-297

Dolzhich, E., Dmitrichenkova, S. (2018). Computer science terminology (a case study of the Spanish language). INTED2018: Proceedings of the 12th International Technology, Education and Development Conference. Valencia, Spain.

Gorev, P., Telegina, N., Karavanova, L., Feshina, S. (2018). Puzzles as a didactic tool for development of mathematical abilities of junior schoolchildren in basic and additional mathematical education. EURASIA: Journal of Mathematics, Science and Technology Education, 14(10): 178-185.

Ivcevic, Z., Brackett, M.A., Mayer, J.D. (2015). Emotional intelligence and emotional creativity. Retrieved from: http://oxbow.sr.unh.edu/zivcevic

Keyfer. D. (2008). Phenomena of social creativity. Creativity Research Journal. Retrieved from: http://oxbow.sr.unh.edu/keyfer

Moroz, V.V. (2011). Development of students' creativity. Orenburg: State University Publishing House.

Oon-Seng, T. (2017). Problem-based Learning and Creativity. Singapore: Cengage Learning Asia Pte Ltd.

Runco, M.A. (2015). Creativity Theories and Themes: Research, Development, and Practice. San Diego: Elsevier Inc.

Sharonova, S., Trubnikova, N., Sokolova, N. (2018). Interpreting religious symbols as basic component of social value formation. European Journal of Science and Theology, 14(3): 117-129.

Vasbieva, D.G., Sokolova, N.L., Masalimova, A.R., Shinkaruk, V.M., Kiva-Khamzina, Y.L. (2018). Exploring the EFL teacher's role in a smart learning environment - a review study. XLinguae, 11(2): 265-274.

Volkova, Y., Panchenko, N. (2018). Discourse variation of the concepts of destructive emotions. Vestnik Rossiiskogo Universiteta Druzhby Narodov. Russian journal of linguistics, 22(1): 175-194. 